\title{
Contegra Graft in the Surgical Management of Double Outlet Right Ventricle (DORV)-A
}

\section{Case Report}

\author{
Rezwanul Hoque*, Shanker Bhandari and Apurba Thakur \\ Resident of Cardiovascular and Thoracic Surgery, Bangabandhu Sheikh Mujib Medical University, Bangladesh
}

Submission: February 11, 2017; Published: March 07, 2017

*Corresponding author: Rezwanul Hoque Bulbul, Professor of Cardiac surgery, Bangabandhu Sheikh Mujib Medical University, Shahbag, Dhaka, Bangladesh, Email: drrhbulbul@yahoo.com

\begin{abstract}
DORV is a complex congenital heart disease where both great vessels arise entirely or predominantly from right ventricle. This report describes the case of a 10 year old female with DORV. The cardiac anomalies were corrected with split Dacron patch for VSD and contegra conduit graft for reconstruction of right ventricular outflow tract. She showed excellent postoperative outcome and was discharged with advice to be on a regular follow up.

Keywords: Double outlet right ventricle; Ventricular septal defect; Contegra graft

Abbreviations: RVOT: Right Ventricular Outflow Tract; DORV: Double Outflow Right Ventricle
\end{abstract}

\section{Introduction}

The spectrum of DORV is complex, heterogeneous and varies between Tetralogy of Fallots (TOF) at one end and complete Transposition of great arteries (TGA) at the other end and surgical correction also varies according to the complexity of the situation [1]. When more than $50 \%$ of the great arteries arise from right ventricle, it is accepted as DORV. The DORV may be of four subtypes:

a) Subaortic.

b) Subpumonary.

c) Doubly committed.

d) Non-committed, according to the relationship of the Ventricular septal defect (VSD) to the great arteries [2].

The definitive management of DORV is always surgical. The contegra grafts are derived from bovine internal jugular vein with its trileaflet venous valve, preserved in buffered glutaraldehyde solution, available as $10-22 \mathrm{~mm}$ size, are readily available from shelf for right ventricular outflow tract (RVOT) reconstruction where homografts or composite pulmonary conduits fail or are not easily available [3] (Figure 1).

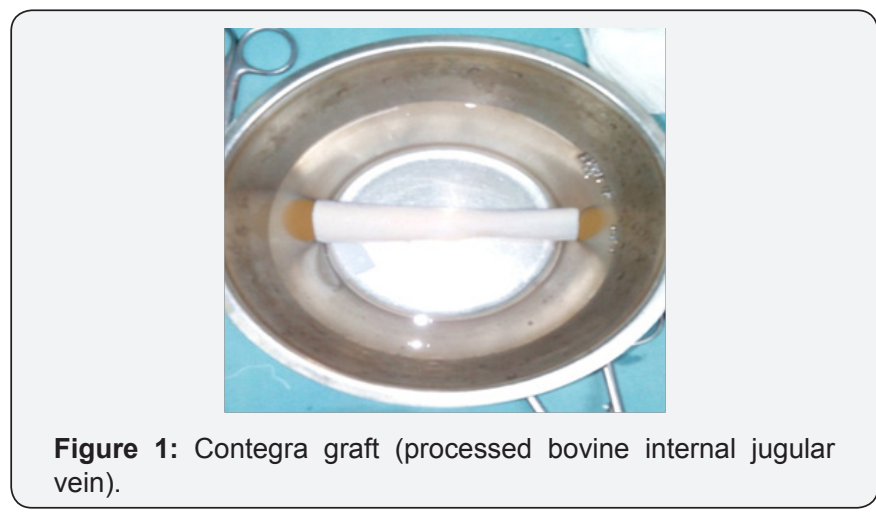

\section{Clinical Summary}

A 10-year-old girl was admitted into cardiac surgery department of BSMMU, with central and peripheral cyanosis since 7-8 months of her birth and gradually worsening shortness of breath on exertion in last few months. On admission she was $133 \mathrm{~cm}$ in height, $24 \mathrm{~kg}$ in weight and her pulse rate was 114 beats per minute, respiration rate was $24 / \mathrm{min}$, blood pressure was $100 / 50 \mathrm{~mm}$ of $\mathrm{Hg}$. She had finger and toe clubbing, moderately bulged out precordium, systolic thrill and murmur 
in the pulmonary area. Chest x-ray revealed typical boot-shaped heart, EKG showed obvious right ventricular hypertrophy, color Doppler echocardiography showed $16 \mathrm{~mm}$ subaortic VSD with predominantly right to left shunt, with more $50 \%$ overriding of aorta, with severe infundibular, valvular and main pulmonary stenosis having transvalvular peak pressure gradient more than $105 \mathrm{~mm}$ of $\mathrm{Hg}$, but having left ventricular ejection fraction of $71 \%$. MDCT revealed the sizes of main pulmonary artery $(8 \mathrm{~mm})$, right pulmonary artery $(10.7 \mathrm{~mm})$, left pulmonary artery $(16.4 \mathrm{~mm})$ respectively, the main pulmonary artery was less than $25 \%$ of the aorta, pulmonary valve was very narrow with fibrosis and speckles of calcification. Major aortopulmonary collaterals were absent however. Cardiac catheterization was not done, because we thought it redundant (Figure 2).

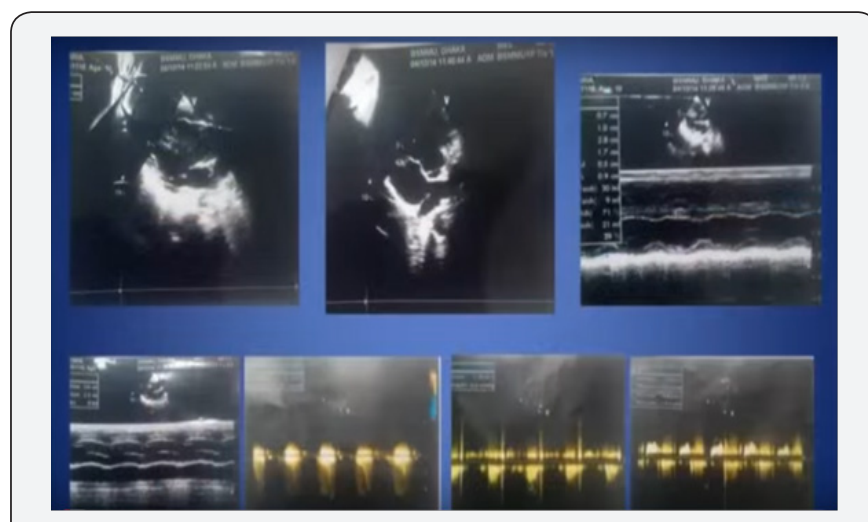

Figure 2: Color Doppler echocardiograph showing DORV.

\section{Procedure Details}

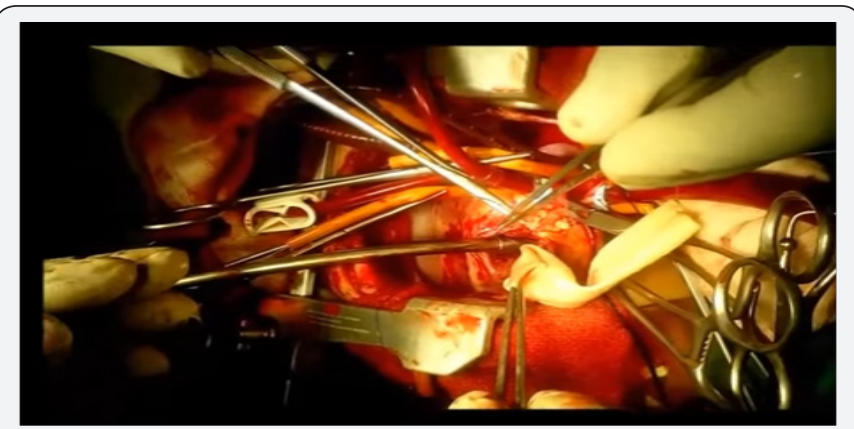

Figure 3: Reconstruction of RVOT with Contegra graft.

The patient was operated on 19 January, 2015. Under general anesthesia with endotracheal intubation and broad spectrum antibiotic coverage, standard median sternotomy and pericardiotomy was done to expose the heart. Cardiopulmonary bypass was established with bicaval cannulation and aortic cannulation. Heart was arrested with aortic root antegrade cardioplegia and mild hypothermia $\left(32{ }^{\circ} \mathrm{C}\right)$ after application of cross-clamp. The subarterial VSD was approached through right vetriculotomy, RVOT muscle bands were resected, VSD was enlarged anteriorly and was repaired by a split-opened Dacron tube graft to produce intracardiac buffle, it reduced the right ventricular cavity size. The severely stenosed main pulmonary artery was resected, proximal end was closed with double layered prolene suture, the right ventriculotomy was anastomed obliquely to the proximal end of Contegra graft $(20 \mathrm{~mm})$ which enlarged the right ventricular cavity to some extent, the distal end of the graft was anastomosed to split-opened, enlarged distal pulmonary artery. The weaning from bypass, recovery in the ICU were uneventful (Figure 3).

\section{Results}

The patient was advised to take Aspirin 75mg daily and was discharged home after 14 days. Follow-up at 1 month, 3 months, 6 months revealed well-functioning graft with an acceptablegradient $(25-35 \mathrm{~mm} \mathrm{Hg})$. However from 9 monthsonward, there is a tendency of increasing gradient, at present, it is $45-50 \mathrm{~mm}$ of $\mathrm{Hg}$, but the patient is asymptomatic. We have kept her on low diuretics, low-dose propranolol, and ambrisentan. We will follow her up regularly to see the longterm patency of the graft and timing of a second look operation.

\section{Discussion}

Double outlet right ventricle (DORV) refers to family of anatomically related complex congenital cardiac lesions involving the outflow tracts. The selection of the operative technique depends on the VSD's position and its relationship to the great arteries [4]. We reconstructed the RVOT with contegra graft and VSD with Dacron patch to produce the intracardiac baffle. The contegra valved heterograft conduit has emerged as a reliable alternative for the reconstruction of right ventricular outflow tract. Contegra conduit device was granted as humanitarian use device in 2002 and approved to profit on the sale of contegra in the year 2013 [3]. Availability of different sizes, suitable alternative to cryopreserved homografts, easy to perform reconstructive procedure due to adequate length and moderate costs make it as a good alternative. Moreover, early postoperative and mid-term results have been satisfactory [5]. One study reported $96 \%$ rate of survival at 5 years and 10 years respectively, freedom from re-intervention $65.2 \%$ at 10 years, freedom from endocarditis $94.4 \%$ at 5 years and 10 years interval, pulmonary insufficiency/ stenosis in $38.5 \%$ during mean follow-up of 10 months. Similarly, pressure gradient $\geq 50 \mathrm{~mm} \mathrm{Hg}$ was $79.9 \%$ at 5 years and $63.5 \%$ at 10 years respectively [6].

\section{Conclusion}

The surgical treatment of DORV is complex and challenging. Our experience of using contegra conduit graft for the reconstruction of RVOT has shown excellent outcome. It may be the treatment of choice for complex congenital heart disease in need of RVOT reconstruction. Extensive clinical trials are needed to understand the efficacy of contegra conduit graft as a treatment of choice for RVOT reconstruction in complex congenital heart disease.

\section{References}

1. Lev M, Bharati S, Meng CC, Liberthson RR, Paul MH, et al. (1972) A concept of double outlet right ventricle. J Thorac Cardiovasc Surg 64(2): 271-281. 
2. Ahmet S, Ebru A, Zeynel G, Mehmet O, Dursun O (2016) Double Outlet Right Ventricle with Discordant Atrioventricular Connections in a Newborn: Case Report and Brief Overview of the Literature. J Clin Anal Med 7(1): 105-108.

3. http://www.fda.gov/downloads/AdvisoryCommittees / Committees MeetingMaterials/PediatricAdvisoryCommittee/ UCM519891.pdf

4. Obler D, Juraszek AL, Smoot LB, Natowicz MR (2008) Double outlet right ventricle: aetiologies and associations. J Med Gent 45(8): 481491.

This work is licensed under Creative Commons Attribution 4.0 License

DOI: $10.19080 /$ JOCCT.2017.03.555617
5. Sfyridis PG, Avramidis DP, Kirvassilis GV, Zavaropoulus PN, Papagiannis JK, et al. (2011) The Contegra ${ }^{\circledR}$ valved heterograft conduit for right ventricular outflow tract reconstruction: a reliable solution. Hellenic J cardiol 52(6): 501-508.

6. Sarikouch S, Horke A, Tudorache I, Beerbaum P, Boethig D, et al. (2016) Decellularized fresh homograft for pulmonary valve replacement: a decade of clinical experience. Eur J Cardio thoracic Surg 50(2): 281290.

\section{Your next submission with Juniper Publishers will reach you the below assets}

- Quality Editorial service

- Swift Peer Review

- Reprints availability

- E-prints Service

- Manuscript Podcast for convenient understanding

- Global attainment for your research

- Manuscript accessibility in different formats

( Pdf, E-pub, Full Text, Audio)

- Unceasing customer service

Track the below URL for one-step submission https://juniperpublishers.com/online-submission.php 